\title{
Population Ageing in India and West Bengal among Scheduled Castes (SC) Population
}

\author{
Archita Nayak ${ }^{1 *}$ and K.K. Bagchi ${ }^{2}$ \\ ${ }^{1}$ Department of Commerce, Kalipada Ghosh Tarai Mahavidyalaya, Darjeeling, West Bengal, India \\ ${ }^{2}$ Department of Economics, University of North Bengal, Darjeeling, West Bengal, India \\ *Corresponding author: archita.nayak@gmail.com
}

\begin{abstract}
The present study deals with the phenomenon of population ageing among SC population in India and West Bengal. Remarkable shrinkages of population pyramids on SC population for India and West Bengal over 2001-2011 indicates a decline in fertility leading to an increase in the proportion of elderly population. More per cent of elderly females are living in West Bengal than those in India. Per cent of working elderly among SC population is lesser than that among ST population in India and West Bengal. Per cent of working elders among SC population in West Bengal is very low compared to that in India. Per cent of currently married elderly among SC population is higher than that among ST population in both India and West Bengal. Prevalence of disabilities of elderly among SC population is almost similar to elderly among ST population both in India and West Bengal. Literacy rate of elderly among SC population in West Bengal is better than that in India. Literacy rate among elderly females of SC population is very low compared to that of elderly males. Elderly persons among SC population are in a better position compared to ST population both in India and West Bengal.
\end{abstract}

Keywords: Population Pyramid, Decadal growth rate, Elderly in general population, Elderly in elderly population, Sex ratio, Literacy rate, Preston Curve

The objective of the present study is to assess and compare the situations of population ageing and social security of the elderly persons among scheduled castes (SC) in India and West Bengal. According to Census of India, 2011, per cent of SC population to total population in India and West Bengal are 16.6 and 23.5 respectively. Top two districts in West Bengal with respect of SC populations are Coochbehar and Jalpaiguri having 50.2 and 37.7 per cent SC population to total populations respectively; both of them belong to North Bengal. Again Jalpaiguri district is in the first position in West Bengal with respect of ST population. District Kolkata is in the lowest position with respect to SC population having only 5.4 per cent of SC population to total population. Like scheduled tribes, scheduled castes population is also a weaker/backward section of society in India.
Another weaker/backward section of society in India is other backward class (OBC). The backwardness of scheduled castes population is not extremely serious compared to that belonging to scheduled tribes population. Office of the Registrar General and Census Commissioner, India, Ministry of Home Affairs, Government of India have been collecting Indian census data for (a) general population, (b) population religious group wise, (c) scheduled castes population and (d) scheduled tribes population. We made an attempt to explore previous studies on population ageing among SC population in India and abroad, but no such works could be traced. The present study is based on the secondary data collected from census of India for the census 2001 and 2011 on SC population. Comparisons of figures on SC population have been done with the corresponding figures on ST population. 


\section{Data and Methodology}

Secondary data relating to population from Census of India 2001-2011 have been used for analyses and presentation. Data have been presented in figures and tables.

\section{Population Ageing in India and West Bengal}

Age-sex distributions of SC population in India and West Bengal are provided through the following population pyramids (Figs 1 and 2). The change from a very broad base in 2001 to a shrunken base in 2011 indicates a decline in fertility leading to an increase in the proportion of elderly population. Again, the rate of shrinking of population pyramid over 2001-2011 in case of Indian SC population is lesser than that in case of SC population of West Bengal indicates that the rate of increase of ageing in case of Indian SC population is lesser than SC population of West Bengal.

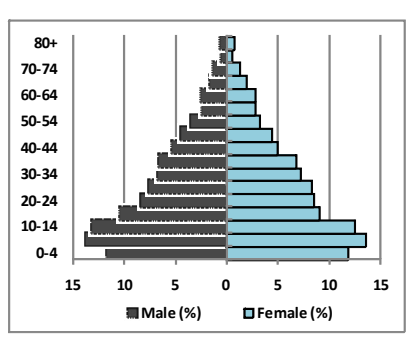

India (SC): 2001

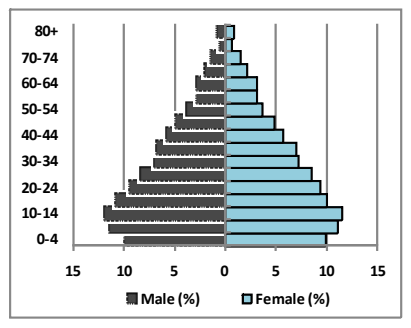

India (SC): 2011
Fig. 1: Population Pyramids for India (SC) for 2001 and 2011

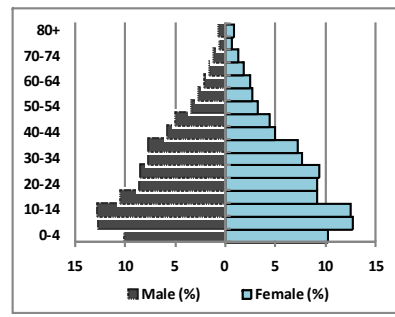

West Bengal (SC): 2001

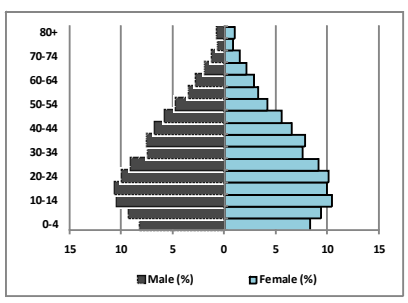

West Bengal (SC): 2011
Fig. 2: Population Pyramids for West Bengal (SC) for 2001 and 2011

Per cent distribution of SC population by age groups according to census 2001 and 2011 along with per cent decadal growth rate of elderly in general and elderly population over 2001-2011 in India and West Bengal according to censuses 2001 and 2011 is provided in Table 1. For SC population, per cent of population aged 0-14 years decreased over years 2001-2011, but there are increasing trends in per cent of population for other age-groups. Per cent decadal growth rate of elderly of SC population in their elderly population over 2001-2011 is almost same in India and West Bengal and among male and female elderly. Per cent decadal growth rate of elderly of SC population in their general population is West Bengal is higher than that in India. Female elderly of SC population both in India and West Bengal has higher per cent of elderly to total population than male elderly.

Per cent of elderly in the age-groups 60-64, 65-69, 70-74, 75-79, 80- and 60- among SC population in India and West Bengal is provided in Table 2. About 1 per cent of female among SC population in West Bengal are aged 80 years and above.

Sex ratio of elderly and general population among SC population in India and West Bengal according to census 2011 is provided in Table 3. It is observed that among SC population, sex ratios of elderly and of general population in West Bengal are higher than those in India except in the age-group 60-64 years. Sex ratio of elderly aged 80 years and above among SC population in West Bengal is 1264. From the figures of Tables 1-3, it may be inferred that there is an increasing trend in population ageing among females of SC population.

From the figures of Tables 1-3, it may be inferred that there is an increasing trend in population ageing among females of SC population.

Per cent distribution of households by number of elderly members in the households among SC population in India according to Sample Registration System (SRS) Baseline Survey, 2014 is provided in Table 4.

Per cent distribution of households with at least an elderly member and at least one member aged 18-59 years by social groups in India according to Sample Registration System (SRS) Baseline Survey, 2014 is provided in Table 5.

Nearly 80 per cent of households in India among all social groups are having at least one elderly member and at least one member aged 18-59 years (normal working age group). From the Tables 4 and 5, it may be inferred that per cent of households having at least one elderly member among SC population is very low compared to almost all other communities in India. 
Table 1: Per cent distribution of elderly population by age groups among SC populations in India and West Bengal in 2001 and 2011

\begin{tabular}{|c|c|c|c|c|c|c|c|c|c|}
\hline & & \multicolumn{6}{|c|}{ Age groups (years) } & \multirow{3}{*}{ 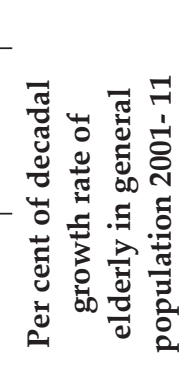 } & \multirow{3}{*}{ 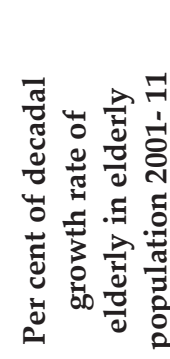 } \\
\hline & & \multicolumn{2}{|c|}{$\stackrel{t}{\stackrel{1}{0}}$} & \multicolumn{2}{|c|}{$\begin{array}{l}\text { ถి } \\
\text { 12 } \\
\text { ம் }\end{array}$} & \multicolumn{2}{|c|}{ 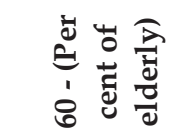 } & & \\
\hline & & ఫ્ڤે & ت्ञ̄ & ఫ్̊ి & ت्ञ & ఠ్రి & 록 & & \\
\hline \multirow{3}{*}{ India } & Person & 38.2 & 32.9 & 54.9 & 59.2 & 6.9 & 7.8 & 12.3 & 37.4 \\
\hline & Male & 38.6 & 33.3 & 54.9 & 59.3 & 6.5 & 7.4 & 11.9 & 37.0 \\
\hline & Female & 37.9 & 32.6 & 54.9 & 59.2 & 7.2 & 8.2 & 12.8 & 37.9 \\
\hline \multirow{3}{*}{$\begin{array}{l}\text { West } \\
\text { Bengal }\end{array}$} & Person & 35.3 & 28.1 & 58.3 & 64.3 & 6.4 & 7.6 & 15.1 & 38.5 \\
\hline & Male & 35.3 & 27.9 & 58.9 & 64.9 & 5.8 & 7.2 & 15.4 & 42.7 \\
\hline & Female & 35.3 & 28.2 & 57.7 & 63.7 & 7.0 & 8.1 & 14.8 & 34.8 \\
\hline
\end{tabular}

Table 2: Per cent of elderly in the age-groups 60-64, 65-69, 70-74, 75-79, 80- and 60- among SC populations in India, West Bengal

\begin{tabular}{cccccccc}
\hline & & $\mathbf{6 0 - 6 4}$ & $\mathbf{6 5 - 6 9}$ & $\mathbf{7 0 - 7 4}$ & $\mathbf{7 5 - 7 9}$ & $\mathbf{8 0 -}$ & $\mathbf{6 0 -}$ \\
\hline \multirow{3}{*}{ India } & Person & 3.0 & 2.0 & 1.4 & 0.6 & 0.8 & 7.8 \\
& Male & 2.8 & 1.9 & 1.4 & 0.6 & 0.7 & 7.4 \\
& Female & 3.1 & 2.2 & 1.5 & 0.6 & 0.8 & 8.2 \\
\multirow{3}{*}{ West Bengal } & Person & 2.8 & 2.0 & 1.3 & 0.7 & 0.8 & 7.6 \\
& Male & 2.7 & 1.9 & 1.2 & 0.6 & 0.7 & 7.2 \\
& Female & 2.9 & 2.1 & 1.5 & 0.7 & 1.0 & 8.1 \\
\hline
\end{tabular}

Source: Census of India, 2011

Table 3: Sex ratios of among SC population in India and West Bengal

\begin{tabular}{cccccccc}
\hline & \multicolumn{7}{c}{ Age groups (in years) } \\
\hline & $\mathbf{6 0 - 6 4}$ & $\mathbf{6 5 - 6 9}$ & $\mathbf{7 0 - 7 4}$ & $\mathbf{7 5 - 7 9}$ & $\mathbf{8 0 -}$ & $\mathbf{6 0 -}$ & All ages \\
\hline India & 1034 & 1051 & 988 & 1083 & 1133 & 1043 & 946 \\
West Bengal & 989 & 1068 & 1131 & 1160 & 1264 & 1074 & 951 \\
\hline
\end{tabular}

Source: Census of India, 2011

Table 4: Per cent distribution of households by number of elderly members in households among SC population in India (as on 1.1.2014)

\begin{tabular}{cccc}
\hline \multicolumn{4}{c}{ Number of elderly members } \\
\hline None & $\mathbf{1}$ & $\mathbf{2}$ & $\mathbf{3 +}$ \\
\hline 77.3 & 15.8 & 6.7 & 0.2 \\
\hline
\end{tabular}

Source: SRS Baseline Survey, 2014

As per census 2011 among SC population in India and West Bengal, per cent of working elders (main worker + marginal worker) is provided in Table
6. The situation of working elderly among SC population in West Bengal is very poor compared that in India. Only 7.7 per cent of elderly females of SC population in West Bengal are working. Again per cent of elderly among SC population in India and West Bengal are lesser than those among ST population in India and West Bengal.

As per census 2011 in India among SC population in India and West Bengal, per cent of currently married elderly is provided in Table 7. Per cent of currently married male elderly among SC population in West Bengal is higher than that in India, but the 
reverse is in case of currently married female elderly among SC population. Per cent of currently married elderly among SC population is higher than that those among ST population in both India and West Bengal.

Table 5: Per cent distribution of households with at least an elderly member \& at least one member aged 18-59 years by social groups in India (as on 1.1.2014)

\begin{tabular}{cccc}
\hline Category & Total & Rural & Urban \\
\hline Total & 81.3 & 80.1 & 84.8 \\
General (excluding SC & 81.4 & 80.2 & 84.7 \\
\& ST) & & & \\
Scheduled & 80.3 & 79.2 & 85.2 \\
Castes (SC) & & & \\
Scheduled & 81.6 & 81.1 & 84.7 \\
Tribes (ST) & & & \\
\hline
\end{tabular}

Source: SRS Baseline Survey, 2014

Table 6: Per cent of working elders among SC population in India and West Bengal according to sex

\begin{tabular}{cccc}
\hline & Person & Male & Female \\
\hline India & 45.4 & 63.0 & 28.5 \\
West Bengal & 26.2 & 46.0 & 7.7 \\
\hline
\end{tabular}

Source: Census of India, 2011
Table 7: Per cent of currently married elderly among SC population in India and West Bengal according to sex

\begin{tabular}{cccc}
\hline & Person & Male & Female \\
\hline India & 63.9 & 81.0 & 47.5 \\
West Bengal & 60.0 & 86.1 & 35.6 \\
\hline
\end{tabular}

Source: Census of India, 2011

Distribution of number of disabled persons per 1000 elderly among SC population in India and West Bengal is provided in Table 8. Numbers of disabled persons per 1000 elderly among SC population in West Bengal are not higher than those in India except for multiple disabilities. Situation of disabilities of elderly among SC population in India and West Bengal is almost similar to elderly among ST population in India and West Bengal.

Per cent distribution of literacy of elderly among SC population in India and West Bengal according to sex for the censuses 2001 and 2011 is provided in Table 9. Literacy level of elderly among SC population in West Bengal is higher than that in India both in censuses 2001 and 2011. There is a tremendous improvement of literacy level over 2001-2011 both in India and West Bengal. Literacy level of elderly females among SC population remains very low

Table 8: Distribution of number of disabled persons per 1000 elderly among SC population in India and West Bengal

\begin{tabular}{|c|c|c|c|c|c|c|c|c|c|}
\hline & \multicolumn{9}{|c|}{ Disability Type } \\
\hline & 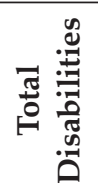 & 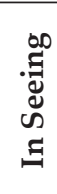 & 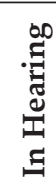 & 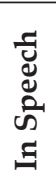 & 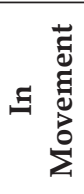 & 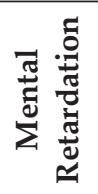 & 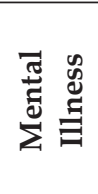 & 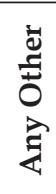 & 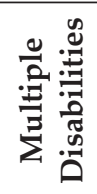 \\
\hline India & 60 & 16 & 11 & 1 & 15 & 1 & 1 & 9 & 7 \\
\hline West Bengal & 53 & 15 & 9 & 1 & 11 & 1 & 1 & 8 & 8 \\
\hline
\end{tabular}

Source: Census of India, 2011

Table 9: Per cent distribution of literacy among elderly in India and West Bengal according to sex among SC population

\begin{tabular}{ccccc}
\hline & & Person & Male & Female \\
\hline \multirow{3}{*}{ India } & 2001 & 20.0 & 33.3 & 7.1 \\
& 2011 & 27.2 & 41.9 & 13.1 \\
& Per cent of decadal growth & 46.6 & 65.1 & 29.2 \\
\multirow{3}{*}{ West Bengal } & 2001 & 31.4 & 53.9 & 11.7 \\
& 2011 & 36.3 & 56.1 & 17.9 \\
& Per cent of decadal growth & 49.1 & 61.4 & 35.8 \\
\hline
\end{tabular}


compared to that of elderly males. Literacy level of elderly males as well as females among SC population remains higher both in India and West Bengal compared to that among ST population. Per cent decadal growth rates of literacy among elderly males of SC population are almost double of those among elderly females of SC population. Thus, females are always lagging behind male population which is a matter of concern.

\section{CONCLUSION}

In the present study, we have explained data relating to population ageing among SC population in India and West Bengal. Population pyramids on SC population for India and West Bengal in censuses 2001 and 2011 have been presented here. Remarkable shrinkages of pyramids on SC population over years 2001-2011 indicates a decline in fertility leading to an increase in the proportion of elderly population. Proportion of population aged 0-14 years decreased over year 2001-2011, but there are increasing trends in population for other age-groups. Sex ratios of elderly among SC population in West Bengal are generally higher than those in India meaning that more elderly females are living in West Bengal than India. Per cent of working elderly among SC population is lesser than that among ST population in India and West Bengal. Per cent of working elders among SC population in West Bengal is very low compared to that in India. Per cent of working female elders among SC population is 7.7 whereas that figure in Indian context is 28.5. Among elders belonging to SC population, about $60,80,40$ per cent person, male and females respectively are currently married in India and West Bengal and that figure is higher than elders among ST population both in India. Regarding disabilities of elderly among SC population in India and West Bengal, vision and movement disabilities are major problems for them. Prevalence of disabilities of elderly among SC population is almost similar to elderly among ST population both in India and West Bengal. Literacy rate of elderly among SC population in West Bengal is better than that in India. Literacy rate among elderly females of SC population is very low compared to that of elderly males. There is a tremendous improvement of literacy rate among elderly of SC population in India and West Bengal. For both India and West Bengal, literacy rate of elderly among SC population is better than that of elderly among ST population. It may be inferred that in both India and West Bengal, elderly among SC population are in a better position compared to ST population. The results echo the hypothesis of Preston Curve that individuals born in richer countries, on average, can expect to live longer than those born in poor countries (Preston, 1975).

\section{REFERENCES}

Preston, S. H. 1975. The Changing Relation between Mortality and Level of Economic Development, Journal of Population Studies, 29(2): 231-248.

Roy, S. 2013. The Emerging Scenario of Population Ageing in West Bengal: Past Trends and Future Direction, Indian Journal of Gerontology, 27(4): 588 - 597.

Singh, C. 2013. Ageing Population in India: Select Economic Issues, Working Paper No. 442, Indian Institute of Management, Bangalore, 27 pages. 